givelsen af Sindssygdom og psykologi og Talens forfatning, der blev genudgivet for nylig, har Hans Reitzels Forlag sørget for, at Foucaults forfatterskab nu i det væsentlige og til stadighed, hvilket må glæde Foucaults store danske læserskare, er tilgængeligt og til at købe i bogladerne på dansk.

Paw Hedegaard Amdisen

\section{Hvad er filosofi?}

Lars Fr. H. Svendsen: Hvad er filosofi?, Arbus: Klim 2003, 142 s., 179 kr.

I den danske oversættelse af Lars Fr. H. Svendsens lettilgængelige bog Hvad er filosofi? karakteriserer han på side 28 filosofi således: 'Filosofien er ... en bevægelse fra det uoverskuelige til det kedelige.' Uden på nogen måde at antyde, at hans undersøgelse af filosofi er kedelig, kan man hævde, at citatet rammer kernen i Svendsens bog, nemlig at give en række overskuelige karakteristikker af filosofien, uden på noget tidspunkt at skjule, at den er en aktivitet, som det er næsten umuligt at give nogen entydig definition.

Bogens kapitler kan inddeles i forskellige emneområder, idet kapitel 1-2 skitserer, hvad filosofien overhovedet kan tænkes at være, og hvad dens grundlag er, mens kapitel 3-5 prøver at karakterisere filosofien i forhold til en række andre aktiviteter som litteratur, videnskab og historie. I kapitel 6 opridses filosofiens stå- sted i dag gennem en oversigt over kontroversen mellem analytisk og kontinental filosofi, og slutteligt giver Svendsen sit bud på, hvad filosofien bør være, ved i kapitel 7-10 at argumentere for et pluralistisk, perspektivisk syn på filosofien som følges af en skarp kritik af nutidig fagfilosofi. Denne kritik udmønter sig primært i påstanden om, at man $i$ de nutidige filosofiske institutioner bedriver en form for filosofi, som udelukkende er fokuseret på specialiserede, tekniske detailundersøgelser, mens man har glemt filosofiens rolle som visdomslære, som en tænkning der også skal forme vores liv i praksis. På trods af dens meget tilgxngelige form er Svendens bog altså ikke uden bid, specielt for en fagfilosof; noget jeg vil vende tilbage til senere.

Hvad er filosofi? udgør således en god og omfattende guide til de mange forskellige elementer som udgør filosofien i dag. Svendsen fremlægger mulige bud på filosofiens udgangspunkt som forundring, fortvivlelse, forvirring; han kommer omkring dens grundlæggende discipliner og problemet med at bestemme disse, lige som han fremlægger det kritiske potentiale i filosofien. Hans sammenligninger mellem filosofien og andre discipliner har også et stort pædagogisk potentiale, idet en af de letteste måder at få et klarere billede af filosofisk arbejde ofte er gennem en forståelse af, hvad det i hvert fald ikke er. Desuden bliver kapitlet om filosofi og litteratur interessant ved 
at problematisere en standardantagelse om filosofi, nemlig at den er rettet mod sandhed, i modsætning til litteraturen som er rettet mod skønhed. Mod denne antagelse fremfører Svendsen at filosofiens sandhedsbegreb er kontekstbundet, og at den er lige så gennemmættet med metaforer som litteraturen, således at dens form ofte nærmer sig den skønlitterære. $\mathrm{Og}$ at filosofien, selv $\mathrm{i}$ de tilfælde hvor den skrives i den tørrest mulige analytiske stil, også altid har en stil. Filosofien er ikke et absolut neutralt rum hvor sandheden kan undersøges; den er ligesom alle andre aktiviteter formet, betinget og begrænset af den måde, den bedrives og formuleres på - selv filosofien kan ikke opdrive en 'skrift uden stil', som det pointeres på side 57. Sympatisk er også påpegningen af filosofiens iboende historicitet, som udspringer af den påvirkning som den faktiske historiske kontekst udøver på filosofiens spørgsmål og udformning. Svendsen pointerer desuden, hvordan filosofien bør have et levende forhold til filosofihistorien, idet han ser dette som en måde, hvorpå filosofien kan fastholde dens altid nødvendige selvrefleksion.

Gennem disse pointer og en lang række andre fremlægger Svendsen i de to forste dele af Hvad er filosofi? et genkendeligt, men også let forenklet billede af filosofien; en forenkling der imidlertid ligger i umiddelbar forlængelse af bogens intention om at være en tilgængelig introduktion til filosofien. Billedet søges nuan- ceret gennem kapitlet om analytisk og kontinental filosofi, der belyser, hvordan opfattelsen af filosofi varierer alt efter hvilke dimensioner, som man værdsætter i det filosofiske arbejde. Jeg tror imidlertid, at netop dette kapitel kan virke sært irrelevant for ikke-filosoffer i dets fremstilling af en indædt, intern fagfilosofisk debat, der, som Svendsen understreger, ofte primært er udsprunget af en helt grundlæggende mangel på forståelse af opponentens synspunkter og faktiske arbejde. Derudover finder jeg det problematisk, at bogen med dette kapitel sætter et generelt fokus på en konflikt, der nu ofte bliver løst på den bedste, $i$ dette tilfælde allermest pragmatiske måde, nemlig ved at mange filosoffer er begyndt at bruge materiale fra både den analytiske og den kontinentale tradition, således at de tidligere så uforenelige fronter taler sammen i meget nutidig tænkning. Som Svendsen selv påpeger i slutningen af kapitlet, overlever forskellene mellem de disse to traditioner ikke længere primært i form af en konflikt, men $i$ form af en filosofihistorisk forståelse af hvordan to traditioner udviklede sig sideløbende. På denne måde kan Svendsens fremstilling virke imod hans hensigt ved at fastholde et modsætningsforhold, som ikke længere har noget reelt indhold.

I den sidste del af bogen fremlægger Svendsen klar vision om, hvad filosofien efter hans mening, bor være. Først og fremmest afviser han enhver idé om, at filosofi har 
et selvstændig og neutralt perspektiv, hvorfra den kan bedrives; ifølge Svendsen vil også filosofien være nødt til at tage udgangspunkt inden for et bestemt perspektiv. Yderligere påpeger han, hvordan det netop ofte er sammenstødet mellem forskellige perspektiver, der starter den filosofiske forvirring, og ønsket om at sætte disse $i$ forhold til hinanden kan eller må derfor ikke tilsidesættes; i stedet skal man passe på ikke at lade sig forlede til at tro, at der findes ét perspektiv, der har eneret på sandhed, for så udvikler perspektivet sig nemt til en form for ideal eller ideologi. Målet med filosofien er derfor ikke det perspektivløse blik på verden, men den tilkæmpede forstålse af at de tilgxngelige perspektiver har begrænset rækkevidde samt en kritisk undersøgelse af samme. Svendsen finder - trods en vis forsigtighed omkring positive udmeldinger om filosofiens nærmere mål - det essentielt, at den bidrager til vores generelle stræben efter at forstå netop dette rodede menneskeliv bedre. Målet for denne stræben benævnes visdom, og et kapitel er reserveret til at uddybe opfattelsen af filosofien som visdomslære: Her ses filosofien ikke bare som en stræben efter indsigt i tilværelsen og verdens beskaffenhed, men efter at bliver i stand til at leve i overensstemmelse med netop denne indsigt. Denne måde at bedrive filosofi, mener Svendsen, i al for høj grad er blevet tilsidesat til fordel for en dygtighedslære eller 'videnskabelig filosofi' i husserlsk forstand. Den grundlæggende fejltagelse ved dette er efter hans mening, at filosofien netop opstår som reaktion på vores behov for forståelighed i tilværelsen, og den visdom som den oprindelig tilstræber ikke blot er teoretisk, men en visdom som man handler efter. Derfor understreger Svendsen også betydningen af, at filosofien fastholder undersøgelsen af det gode liv, af eksistentielle og moralske spørgsmål.

Denne idé om filosofiens betydning for vores generelle stræben efter at forstå tilværelsen følges af en række kritiske punkter i kapitlet 'Fagfilosofiens elendighed'. Svendsen hævder ikke bare, at fagfilosofien trods en stor almen interesse for filosofi har formået at gøre sig selv så teknisk, at den bliver irrelevant for ikke-filosoffer. Han går et skridt videre og hævder ligefrem, at uden en mere direkte kobling til idealet om selvrealisering, kommer den filosofiske forskning til at mangle legitimitet. Ligeledes fremhæves professionaliseringen af filosofi som en mekaniske, der gør det sværere at bedrive filosofi med et bredt sigte, hvilket får filosoffen til at se liv og filosofi som to adskilte størrelser. Dagens filosoffer lever ikke deres tænkning. Således gror den levende tanke ifølge Svendsen til i 'pedanteri': 'I det århundrede, hvor vi sandsynligvis havde mere brug for filosofi end nogensinde, svigtede den mere end nogensinde.' (Side 134).

Jeg har et noget ambivalent i forhold til Hvad er filosofi?s kritiske poin- 
te. Som det er tilfældet med Svendsen forsøg på at indkredse nutidig filosofi vha. konflikten mellem analytisk og kontinental filosofi mener jeg også her at han fortegner diversiteten og målsætningen i den filosofi der bedrives i dag. Generelt kan man hævde at bogens mindre heldige side er at den i sit forsøg på at gøre det overskuelige enkelt $i$ nogle af sine mere positive billeder simpelthen fortegner billedet af nutidig filosofi. Man kan hævde, at Svendsen til dels sætter sig mellem to stole ved at skrive en bog, som umiddelbart er en introduktion til den alment filosofi-interesserede, og så lade denne introduktion følges af en opsang til de mest specialiserede dele af den filosofisk fagelite. Det skal imidlertid understreges, at bogens styrke ligger $i$ dens introducerende karakter. Hvis man er træt af at ens faster, far, teenagebarn eller ægtefælle ikke forstår, hvad 'det der filosofi', man studerer eller arbejder indenfor, nu engang er for noget, så kan man stikke dem Svendsens bog i hånden, for her får de muligheden for at blive klogere på kompleksiteten i netop dette felt. Og før man sender bogen videre til sin faster, kan man evt. læse de sidste kapitler i bogen og selv overveje, om man synes at Svendsen har fat i vigtig pointe: Måske er der dele af de forpligtelser, som filosofiens indebærer, der ikke bliver forvaltet på bedste måde i øjeblikket? Under alle omstændigheder er det altid umagen værd, at man som fagfilosof tager sig et øjeblik til at se op fra sin seneste artikel om eksegetiske spidsfindigheder eller analytisk begrebsudvikling og overvejer, hvilken plads netop dette arbejde har i det store, uheterogene hele, vi kalder filosofi.

Anne-Marie Christensen

\section{Min fars chef havde en fed stil- ling som min fars far \\ Larry Hirschborn: Autoritetsrelationen i nye sammenhange. Hans Reitzels Forlag, 2003, 160 s., 198,00 kr.}

I den patriarkalske kultur afspejlede arbejdslivets organisering en maskulin orden: Drengen vil være som sin far, og fra det øjeblik drengen opdager kraften ved sin egen erigerede penis, forfølger han bevidst målet om at bryde underkastelsen under den faderlige magt og overtage den. Lige sådan var autoritetsrelationerne på arbejdsmarkedet engang præget af klare over- og underordningsforhold mellem mænd. I dag er kvinderne kommet på arbejdsmarkedet og har fået plads bag rattet på gaffeltrucken - alt imens de kære vestlige mænd har smidt futteralerne og er begyndt at interessere sig for mode, følelser og hjemkundskab. Denne indviklede sammenblanding af traditionelle mandlige og kvindelige anliggender genfindes $i$ arbejdsmarkedets autoritetsformer, hvor chef og far nu ikke længere er to sider af samme fornuft. I Larry Hirschhorns bog Autoritetsrelationen $i$ nye sammenhange undersøges 